\title{
CRITICAL APPRAISAL OF EFFECTIVENESS OF ORAL FINGOLIMOD ON RELAPSING MULTIPLE SCLEROSIS
}

\author{
TELAAH KRITIS KEEFEKTIFAN FINGOLIMOD ORAL PADA \\ MULTIPEL SKLEROSIS RELAPS
}

\author{
Rizaldy Taslim Pinzon ${ }^{1 *}$, Rosa De Lima Renita Sanyasi² \\ ${ }^{1}$ Duta Wacana Christian University School of Medicine, Dr. Wahidin Sudirohusodo Street, \\ Number 5-25, Kotabaru, Gondokusuman, Yogyakarta City, Special Region of Yogyakarta, \\ Indonesia, 55224 \\ ${ }^{2}$ Internship Doctor at dr. Efram Harsana Air Force Hospital, Raya Solo Street, Maospati, Magetan, \\ East Java, 63392
}

Received April 19, 2017; Accepted July 25, 2017

\begin{abstract}
Oral fingolimod has been recently accepted as a treatment for relapsing Multiple Sclerosis (MS) by the Indonesian Food and Drug Administration. The number of MS patients is increasing in Indonesia. There is a critical need of systematically reviewing the new medication for both efficacy and safety. This review aimed to appraise the clinical evidences of oral fingolimod for the effective treatment of relapsing MS. We searched in Pubmed database. We limited our search to only articles that were in full text, published within the last 10 years, and in English. We used the Jadad scale to measure the quality of the evidences. We only found 3 trials, all conducted with randomized and double blind design. The three trials were: the FREEDOMS I, FREEDOMS II, and TRANSFORMS studies. The FREEDOMS studies compared with placebo, and the TRANSFORMS study compared with injectable interferon. All of the studies have good quality in methodology (Jadad scale >3). The results of the three studies showed the benefit of oral fingolimod in reducing $M S$ relapse compared with placebo with relative risk reduction range from $48 \%$ to $54 \%$, and also in reducing new lesions in T2 brain MRI with relative risk reduction range from $35 \%$ to $74 \%$. Our critical appraisal found that oral fingolimod improved clinical outcomes. The availability of oral fingolimod in Indonesia makes it one of the options in treatment of MS relapse in Indonesia and has been demonstrated to be effective and safe with relatively small risk.
\end{abstract}

Keywords: critical appraisal, fingolimod, multiple sclerosis, relapsed MS, Indonesia

\begin{abstract}
ABSTRAK
Fingolimod oral baru-baru ini memiliki Nomor Ijin Edar (NIE) dari BPOM untuk multipel sklerosis. Jumlah kasus multipel sklerosis meningkat di Indonesia. Ada kebutuhan untuk melakukan kajian sistematis terhadap efektivitas dan keamanan obat-obat untuk multipel sclerosis. Tujuan dari penelitian ini adalah untuk menilai berbagai penelitian klinis pada fingolimod untuk terapi multipel sklerosis yang relaps. Peneliti melakukan pelacakan pustaka di Pubmed. Pencarian hanya dibatasi untuk artikel yang dapat diperoleh secara bebas, terbit 10 tahun terakhir, dan dipublikasi dalam bahasa inggris. Peneliti menggunakan skor Jadad untuk menilai kualitas penelitian. Kami hanya menjumpai 3 uji klinik dengan disain randomisasi dan double blind. Ketiga uji klinik tersebut adalah: uji klinik FREEDOMS I, uji klinik FREEDOMS II, dan uji klinik TRANSFORMS. Uji klinik FREEDOMS membandingkan fingolimod dengan placebo, dan uji klinik TRANSFORMS membandingkan fingolimod dan interferon injeksi. Semua uji klinik tersebut memiliki kualitas yang baik (skor Jadad >3). Ketiga uji klinik menunjukkan manfaat fingolimod dalam mengurangi relaps disbanding dengan placebo antara 48\%-54\%, dan juga mengurangi lesi baru di
\end{abstract}

*Corresponding author: Rizaldy Taslim Pinzon

Email:drpinzon17@gmail.com 
MRI kepala T2 dengan penurunan risiko relatif berkisar antara 35\%-74\%. Telaah kritis menunjukkan adanya perbaikan luaran dengan fingolimod. Ketersediaan fingolimod di Indonesia menjadikannya sebagai salah satu pilihan dalam terapi efektif dan aman untuk multipel sclerosis di Indonesia.

Kata kunci: telaah kritis, fingolimod, multiple sclerosis, relapse MS, Indonesia

\section{INTRODUCTION}

Multiple sclerosis (MS) is an immune mediated condition that leads to central nervous system (CNS) deterioration (Fitzner and Simons, 2010). In daily clinical practice, over $80 \%$ of patients with MS are identified as RemissionRelapse, which is the most common subtype of the disease (Steinman, 2014). The cause of MS is not known (Loma and Heyman, 2011). Genetics (including race and gender), Epstein-Barr virus infection, and environmental factors (vitamin D deficiency, smoking, geographical location, low exposure to sunlight, birth month) are linked to the disease (Bagheri et al., 2015; O'Gorman et al., 2012; Oreja-Guevara et al., 2014). Multiple sclerosis is thought to be an autoimmune disease mediated by T-cells that leads to the breakdown of the blood brain barrier, allowing inflammatory mediators to enter and attack the CNS, resulting in demyelination and axonal loss (Kasper and Reder, 2014; Wu and Alvarez, 2011). Diagnosis of MS is based on clinical symptoms in combination with evidence of lesions from magnetic resonance imaging (MRI) (Polman et al., 2011). Symptoms vary depending on the location and severity of the CNS lesions (Marcus and Waubant, 2012).

Multiple sclerosis is a chronic disease that can progress intermittently or continuously and is divided into four disease courses: (1) relapsingremitting multiple sclerosis (RRMS), (2) primaryprogressive multiple sclerosis (PPMS), (3) secondary-progressive multiple sclerosis (SPMS), and (4) progressive-relapsing multiple sclerosis (PRMS) (Leary et al., 2005; Lublin et al., 2014). Relapsing-remitting multiple sclerosis is the most common form of MS (Huisman et al., 2017). Most medications used in the treatment of MS are indicated in the treatment of RRMS (Kieseier and Jeffery, 2010).

Relapses are common and represent a major feature of MS (Ross, 2012). A relapse is characterized by episodes of acute worsening of function followed by partial or complete recovery (McKay et al., 2015). The outcome measure of limitations to parenteral disease-modifying therapies (DMTs) such as interferon (IFN) $-\beta-1 \mathrm{a}$, IFN- $\beta-1 b$, and glatiramer acetate for the treatment of RRMS (Weinstock-Guttman, 2013) have been addressed by the approval of oral DMTfingolimod in Indonesia. Fingolimod is an immunotherapeutic drug targeting the sphingosine1-phosphate receptor, and is a widely used medication for RRMS (Ayzenberg et al., 2016) which is metabolized by sphingosine kinase to the active metabolite fingolimod phosphate which in turn blocks the migration of lymphocytes from lymph nodes, thereby reducing the number of lymphocytes in peripheral blood (Goldenberg, 2012).

The number of multiple sclerosis patients is increasing in Indonesia. There is a critical need of systematically reviewing the new medication for multiple sclerosis both for efficacy and safety. The aim of this review is to appraise the clinical evidences of oral fingolimod for the effective treatment of relapsing MS.

\section{METHODS}

A literature search was conducted to identify articles addressing each key question, searching the MEDLINE database, the Cochrane Library, and reference lists of review articles. We searched in Pubmed database using keywords: fingolimod, multiple sclerosis patients, relapsing multiple sclerosis, and clinical trial. We limited our searches only for articles that were full text, published within the last 10 years, and in English. We used the Jadad scale to measure the quality of the evidences (Berger and Alperson, 2009). For the clinical efficacy section, only clinical trials published in English and indexed on MEDLINE, evaluating efficacy of fingolimod with reduction of symptoms or improvement in disease state as an endpoint were included. Trials evaluating fingolimod as monotherapy or combination therapy where adjunctive medications remained constant throughout the trial were also included. Trials comparing monotherapy with combination regimens were excluded.

We excluded clinical trials which evaluated endpoints other than reduction of symptoms, such as lymphocyte count, or immune response. Individual trials comparing fingolimod in dose- 
finding studies or in healthy subjects were also excluded. We measured the quality of the evidences using the Jadad score for evaluating the clinical trial. We calculated the absolute risk reduction (ARR), the relative risk reduction (RRR), and number needed to treat (NNT) for the dichotomous important clinical outcome which was compared with placebo. This review appraised the validity and significance of the previous studies of fingolimod as an effective MS medicine. We also appraised its applicability as a safe treatment for relapsing MS in the Indonesia setting.

\section{RESULTS AND DISCUSSION}

We found 18 trials that measured the effectiveness of oral fingolimod in relapsing multiple sclerosis. We only found 3 trials which were randomized controlled trials (RCTs) with double blind design. The three trials are: FREEDOMS I, FREEDOMS II, and
TRANSFORMS studies. The FREEDOMS studies compared with placebo and the TRANSFORMS study compared with injectable interferon. All of the studies have good quality in methodology (Jadad scale >3).

The FREEDOMS studies were placebocontrolled, double-blind RCTs that compared two doses of fingolimod, $0.5 \mathrm{mg}$ and $1.25 \mathrm{mg}$ once daily, to placebo over a period of 2 years. There were 1272 patients enrolled, with $59 \%$ of whom had never previously been on any form of DMT. The primary endpoint was the annualized relapse rate over the full 2-year study period with other clinical and radiological outcomes examined as secondary endpoints. The annualized relapse rate was 0.40 in the placebo arm, 0.18 in the low dose and 0.16 in the high dose fingolimod arms, corresponding to Relative Risk Reductions (RRR) of $54 \%$ and $60 \%$, respectively $(p<0.05)$.

Table I. Descriptions of the Study

\begin{tabular}{ccccl}
\hline Study & Method & Comparator & Subjects & Result \\
\hline FREEDOMS I & $\begin{array}{c}\text { Randomized, } \\
\text { double blind }\end{array}$ & Placebo & $\begin{array}{c}1272 \text { patients, } \\
1033 \text { completed } \\
\text { the study }\end{array}$ & $\begin{array}{l}\text { Significant reduction of relapse rate in } \\
\text { the Fingolimod group }(0.16 \text { vs } 0.40, \mathrm{p} \\
<0.001)\end{array}$ \\
\hline FREEDOMS II & $\begin{array}{c}\text { Randomized, } \\
\text { double blind }\end{array}$ & Placebo & $\begin{array}{c}1083 \text { subjects, } \\
\text { divided into } 3 \\
\text { groups }\end{array}$ & $\begin{array}{l}\text { Significant reduction in relapse rate } \\
\text { compared with placebo }(0.21 \text { vs } 0.40, \mathrm{p} \\
<0.05)\end{array}$ \\
\hline TRANSFORMS & $\begin{array}{c}\text { Randomized, } \\
\text { double blind }\end{array}$ & $\begin{array}{c}\text { Interferon } \\
\text { beta }\end{array}$ & 1292 subjects & $\begin{array}{l}\text { Significant lower relapse rate either in } \\
0.5 \text { mg or } 1.25 \text { mg Fingolimod } \\
\text { compared with Interferon }(0.16 \text { vs } 0.20 \\
\text { vs } 0.33, p<0.05)\end{array}$ \\
\hline
\end{tabular}

Table II. The Quality Assessment of the Trials

\begin{tabular}{cccccc}
\hline Trials & $\begin{array}{c}\text { Is it } \\
\text { randomized? }\end{array}$ & $\begin{array}{c}\text { Is it double } \\
\text { blind? }\end{array}$ & $\begin{array}{c}\text { Is } \\
\text { randomization } \\
\text { appropriate? }\end{array}$ & $\begin{array}{c}\text { Is the blinding } \\
\text { appropriate? }\end{array}$ & $\begin{array}{c}\text { Is there any } \\
\text { description of } \\
\text { withdrawals } \\
\text { and drop outs? }\end{array}$ \\
\hline FREEDOMS I & Yes & Yes & Yes & Yes & Yes \\
\hline FREEDOMS II & Yes & Yes & Yes & Yes & Yes \\
\hline TRANSFORMS & Yes & Yes & Yes & Cannot tell & Yes \\
\hline
\end{tabular}


Table III. The Summary of Effectiveness of the Study

\begin{tabular}{ccccc}
\hline Trials & Relapse Rate & New Lesion in T2 & $\begin{array}{c}\text { Confirmed } \\
\text { Disability } \\
\text { Progression }\end{array}$ & $\begin{array}{c}\text { Brain Volume } \\
\text { Loss }\end{array}$ \\
\hline FREEDOMS I & $-54 \%$ & $-74 \%$ & $-34 \%$ & $-35 \%$ \\
\hline FREEDOMS II & $-48 \%$ & $-74 \%$ & $-28 \%$ & $-33 \%$ \\
\hline TRANSFORMS & $-52 \%$ & $-35 \%$ & No data & $-31 \%$ \\
\hline
\end{tabular}

Table IV. The Calculation of ARR, RRR, and NNT for Annualized Relapse Rate

\begin{tabular}{cccccc}
\hline Trials & CER & EER & $\begin{array}{c}\text { RRR } \\
\text { (CER-EER) : CER }\end{array}$ & $\begin{array}{c}\text { ARR } \\
\text { (CER-EER) }\end{array}$ & $\begin{array}{c}\text { NNT/ } \\
\text { ARR }\end{array}$ \\
\hline FREEDOMS I & 0.40 & 0.18 & $55 \%$ & $22 \%$ & 4.5 \\
\hline FREEDOMS II & 0.40 & 0.21 & $47.5 \%$ & $19 \%$ & 5.2 \\
\hline TRANSFORM & 0.33 & 0.16 & $51 \%$ & $17 \%$ & 5.88 \\
\hline
\end{tabular}

EER: Experimental Event Rate, CER: Control Event Rate, ARR: Absolute Risk Reduction, RRR: Relative Risk Reductions, NNT: Number Needed to Treat

In contrast to FREEDOMS, TRANSFORMS was a 1-year long, double-blind, double-dummy RCT using an established DMT, with weekly intramuscular IFN-1a as an activecomparator. A total of 1292 patients (45\% treatment-naïve) were randomized in a 1:1:1 treatment allocation. The primary endpoint was the annualized relapse rate, while similar secondary MRI and clinical endpoints were also assessed. The annualized relapse rates were 0.16 in the 0.5 $\mathrm{mg}$ arm and 0.20 in the $1.25 \mathrm{mg}$ arm in contrast to 0.33 in the IFN-1a-treated subjects, corresponding to RRRs of $52 \%$ and $38 \%$, respectively ( $p<0.05$ ).

This review showed that high quality evidences support the use of oral fingolimod as a safe and effective DMT in MS. Treatment of MS varies depending on the clinical subset of MS present and individual patient characteristics. In general, treatment may include treatment of acute relapses, DMT in combination with symptomatic treatment, and complications associated with MS (Pandit and Murthy, 2011). Treatments of moderate-severe acute MS relapses include systemic corticosteroids or adrenocorticotropic hormone (ACTH) therapy (Berkovich, 2013). Symptomatic treatments include glucocorticoid therapy, benzodiazepines, muscle relaxers, anticonvulsants, antidepressants, and medications used to treat bladder and bowel dysfunction (Antezana, 2014). Currently, no curative medication therapies are available in the treatment of MS (Mendes and Sá, 2011). DMTs provide symptomatic relief and reduced MS progression. Many injectable DMTs and oral agents are available for use in MS (Longbrake et al., 2016). DMTs include IFN- $\beta-1 \mathrm{a}$, IFN- $\beta-1 \mathrm{~b}$, glatiramer acetate, teriflunomide, dimethyl fumarate (as the first line medications), mitoxantrone, alemtuzumab, natalizumab, and fingolimod (as the second line medications) (Torkildsen et al., 2015).

The IFN- $\beta$ agents have anti-inflammatory properties as well as their effects on the endothelial cells of the blood brain barrier (Minagar, 2013). Glatiramer acetate is associated with a broader immunomodulatory effect on both the innate and adaptive immune system (Lalive et al., 2011). Teriflunomide acts primarily as an inhibitor of dihydroorotate-dehydrogenase, thereby diminishing the inflammatory response to autoantigen (Oh and O'Connor, 2014). Dimethyl fumarate has immunomodulatory properties exerted through abilities to divert cytokine production toward a Th2 profile (Bomprezzi, 2015). Mitoxantrone is an immunosuppressive drug and considered as an effective therapeutic option in RRMS, but the potential life-threatening adverse events and the overall benefit-risk ratio must be carefully evaluated at the individual patient level (Esposito et al., 2010). Both alemtuzumab, an anti-CD52 antibody, and 
natalizumab seem highly effective and viable immunotherapies for MS (Kalincik et al., 2017).

The trials showed that fingolimod significantly improved annualized relapse rates and MRI endpoints when compared to IFN and placebo. Most of its benefits are neuroprotective and reparative (Williams et al., 2014). Our critical appraisal and evaluation of fingolimod, the oral sphingosine-1- phosphate (S1P) inhibitor, suggests fingolimod is safe and effective in reducing acute MS attacks and may be a more convenient treatment option for patients.

Fingolimod has proven its effectiveness in reducing relapse rate, disability progression, MRI activity, and brain volume loss (Fonseca, 2015). In MS, fingolimod appears to prevent normal lymphocyte egress from lymphoid tissues, thus reducing the infiltration of autoaggresive lymphocytes into the CNS, where they would cause inflammation and tissue damage (Chun and Hartung, 2010). The clinical data showed that lymphocyte count decreases within 6 hours of the first dose of fingolimod and will return to normal 1-2 months after discontinuing the drug. Fingolimod therapy also results in decreased neutrophil count but does not reduce monocyte count (Archer and Oderda, 2013).

The long half-life of fingolimod, together with its slow absorptions, means that fingolimod has a flat concentration profile over time with once-daily dosing (David et al., 2012). After administration, fingolimod is largely distributed into red blood cells, has a large volume of distribution $(1,200 \mathrm{~L})$, is highly plasma protein bound and is primarily metabolized by hepatic CYP4F2. Fingolimod is renally excreted and no dosage adjustments are required for patients with renal or hepatic dysfunction (Archer and Oderda, 2013).

Treatment with fingolimod was well tolerated and no patients had any severe adverse events (Totaro et al, 2015). This review revealed there were some side effects from administering fingolimod, such as bradycardia, first or second heart block, macular edema, increased serum alanine aminotransferase (ALT), lymphopenia, and infection. Most of those side effects were infrequent and resolved with discontinuation of fingolimod (Nicholas et al., 2012).

Multiple sclerosis is a chronic disabling condition. The prevention of relapse is the main objective of multiple sclerosis management (Berkovich, 2013). This review found that the Number Needed to Treat (NNT) for prevention of one relapse is 5 . It means that we have to treat 5 patients with multiple sclerosis to prevent one relapse during the treatment period. The NNT between 2-5 indicates that the medication is effective (Berger and Alperson, 2009). Fingolimod oral administration is simpler than subcutaneous interferon injection. It makes fingolimod more applicable in clinical setting.

\section{CONCLUSION}

Fingolimod was the first introduced oral disease-modifying agent approved for the treatment of relapsing MS. Our critical appraisal found that oral fingolimod improved clinical outcomes. Fingolimod also has relatively good tolerability. The availability of oral fingolimod in Indonesia makes it one of the safe and effective options in the treatment of multiple sclerosis in Indonesia. Oral administration of fingolimod makes it more applicable in clinical setting compared with subcutaneous interferon injection.

\section{REFERENCES}

Antezana, A., 2014. Symptomatic Management of Multiple Sclerosis. The Neurol Report., 7 (1), 39-46.

Archer, M., Oderda, G., 2013. Fingolimod (Gilenya®) Drug Review. University of Utah, College of Pharmacy.

Ayzenberg, I., Hoepner, R., and Kleiter, I., 2016. Fingolimod for Multiple Sclerosis and Emerging Indications: Appropriate Patient Selection, Safety Precautions, and Special Considerations. Ther Clin Risk Manag., 12, 261-272.

Berger, V.W., Alperson S.Y., 2009. A General Framework for The Evaluation of Clinical Trial Quality. Rev Recent Clin Trials, 4 (2), 78-88.

Berkovich, R., 2013. Treatment of Acute Relapses in Multiple Sclerosis. Neurotherap., 10, 97 105.

Bomprezi, R., 2015. Dimethyl Fumarate in the Treatment of Relapsing-Remitting Multiple Sclerosis: An Overview. Ther Adv Neurol Disord., 8 (1), 20-30.

Chun, J., Hartung, H.P., 2010. Mechanism of Action of Oral Fingolimod (FTY720) in Multiple Sclerosis. Clin Neuropharmacol., 33 (2), 91-101.

David, O.J., Kovarik, J.M., Schmouder, R.L., 2012. Clinical Pharmacokinetics of Fingolimod. Clin Pharmacokinet., 51 (1), 15-28.

Esposito, F., Radelli, M., Martinelli, V., Sormani, 
M.P., Boneschi, F.M., Moiola, L., Rocca, M.A., Rodegher, M., Comi, G., 2010. Comparative Study of Mitoxantrone Efficacy Profile in Patients with RelapsingRemitting and Secondary Progresive Multiple Sclerosis. Sage Journ., 16 (12), 1490-1499.

Fitzner, D., Simons, M., 2010. Chronic Progressive Multiple Sclerosis Pathogenesis of Neurodegeneration and Therapeutic Strategies. Current Neuropharmacol., 8, 305-315.

Fonseca, J., 2015. Fingolimod Real World Experience: Efficacy and Safety in Clinical Practice.

Goldenberg, M.M., 2012. Multiple Sclerosis Review. P\&T., 37 (3), 175-184.

Huismann, E., Papadimitropoulou, K., Jarrett, J., Bending, M., Firth, Z., Allen, F., Adlard, N., 2017. Systematic Literature Review and Network Meta-analysis in Highly Active Relapsing-Remitting Multiple Sclerosis and Rapidly Evolving Severe Multiple Sclerosis. BMJ Open, DOI: 10.1136/bmjopen-2016013430.

Kalincik, T., Brown, J.W.L., Robertson, N., Willis, M., Scolding, N., Rice, C.M., Wilkins, A., Pearson, O., Ziemssen, T., Hutchinson, M., McGuigan, C., Jokubaitis, V., Spelman, T., Horakova, D., Hardova, D., Trojano. M., Izquierdo, G., Lugaresi, A., Prat, A., Giard, M., Duquette, P., Grammond, P., Alroughani, R., Pucci, E., Sola, P., Hupperts, R., Lechner-Scott, J., Terzi, M., Van Pesch, V., Rozca, C., GrandMaison, F., Boz, C., Granella, F., Slee, M., Spitaleri, D., Olascoaga, J., Bergamaschi, R., Verheul, F., Vucic, S., McCombe, P., Hodgkinson, S., Sanchez-Menoyo, J.L., Ampapa, R., Simo, M., Csepany, T., Ramo, C., Cristiano, E., Barnett, M., Butzkueven, H., Coles, A., 2017. Treatment Effectiveness of Alemtuzumab Compared with Natalizumab, Fingolimod and Interferon Beta in Relamsing-Remitting Multiple Sclerosis: A Cohort Study. Lancet Neurol., 16 (4), 271281.

Kasper L.H., Reder, A.T., 2014. Immunomodulatory Activity of InterferonBeta. Annals of Clin and Translational Neurol., 1 (8), 622-631.

Kieseier, B.C., Jeffery D.R., 2010. Chemotherapeutics in the Treatment of Multiple Sclerosis. Ther Adv Neurol Disord., 3 (5), 277-291.
Lalive, P.H., Neuhaus, O., Benkhoucha, M., Burger, D., Hohlfeld, R., Zamvil, S.S., Weber, M.S., 2011. Glatiramer Acetate in the Treatment of Multiple Sclerosis: Emerging Concepts Regarding Its Mechanism of Action. CNS Drugs., 25 (5), 401-414.

Leary, S.M., Parter B., Thompson, A.J., 2005. Multiple Sclerosis: Diagnosis and the Management of Acute Relapse. Postgrad Med J., 81, 302-308.

Loma, I., Heyman, R., 2011. Multiple Sclerosis: Pathogenesis and Treatment. Current Neuropharmacol., 9, 409-416.

Longbrake, E.E., Cross, A.H., Salter, A., 2016. Efficacy and Tolerability of Oral Versus Injectable Disease-Modifying Therapies for Multiple Sclerosis in Clinical Practice. Experiment Translation and Clin., 2, 1-10.

Lublin, F.D., Reingold, S.C., Cohen, J.A., Cutter, G.R., SØrensen P.S., Thompson, A.J., Wolinsky, J.S., Balcer L.J., Banwell B., Barkhof, F., Bebo, B., Calabresi, P.A., Clanet M., Comi, G., Fox, R.J., Freedman, M.S., Goodman, A.D., Inglese, M., Kappos, L., Kieseier, B.C., Lincoln, J.A., Lubetzki, C., Miller, A.E., Montalban, X., O’Connor, P.W., Petkau, J., Pozzili, C., Rudick, R.A., Sormani, M.P., Stüve, O., Waubant, E., Polman, C.H., 2014. Defining the Clinical Course of Multiple Sclerosis. Neurol., 83, 278-286.

Marcus, J.F., Waubant, A.L., 2012. Updates on Clinically Isolated Syndrome and Diagnostic Criteria for Multiple Sclerosis. The Neurohospital. 3 (2), 65-80.

McKay, K.A., Kwan, V., Duggan, T., Tremlett, H., 2015. Risk Factors Associated with the Onset of Relapsing-Remitting and Primary Progressive Multiple Sclerosis: A Systematic Review. BioMed Research Intern., DOI: 10.1155/2015/817238.

Mendes, A., Sá, M.J., 2011. Classical Immunomodulatory Therapy in Multiple Sclerosis: How It Acts, How It Works. Arg Neurosiquiatr., 69 (3), 536-543.

Minagar, A., 2013. Current and Future Therapies for Multiple Sclerosis. Scientifica. DOI: 10.1155/2013/249101.

Nicholas, J., Morgan-Followell, B., Pitt, D., Racke, M.K., and Boster, A., 2012. New and Emerging Disease-Modifying Therapies for Relapsing-Remitting Multiple Sclerosis: What is New and What is to Come. Journal of CNS Disease, 4, 81-103. 
O’Gorman, C. Lucas, R., Taylor, B., 2012. Environmental Risk Factors for Multiple Sclerosis: A Review with a Focus on Molecular Mechanisms. Int. J. Mol. Sci., 13, 11718-11752.

Oh, J., O’Connor, P.W., 2014. Teriflunomide in the Treatment of Multiple Sclerosis: Current Evidence and Future Prospects. Ther $A d v$ Neurol Disord., 7 (5), 239-252.

Oreja-Guevara, C., Wiendl, H., Kieseier, B.C., Airas, L., 2014. Specific Aspects of Modern Life for People with Multiple Sclerosis: Considerations for the Practitioner. Ther Adv Neurol Disord., 7 (2), 137-149.

Pandit, L., Murthy, J.M.K., 2011. Treatment of Multiple Sclerosis. Ann India Acad Neurol., 14 (Supp11), S65-S69.

Polman, C.H., Reingold, S.C., Banwell, B., Clanet, M., Cohen, J.A., Filippi, M., Fujihara, K., Havrdova, E., Hutchinson, M., Kappos, L., Lublin, F.D., Montalban, X., O’Connor, P., Sandberg-Wolheim, M., Thompson, A.J., Waubant, E., Weinshenker, B., Wolinsky, J.S., 2011. Diagnostic Criteria for Multiple Sclerosis: 2010 Revisions to the McDonald Criteria. Ann Neurol., 69, 292-302.

Ross, A.P., Halper, J., and Harris, C.J., 2012. Assessing Relapses and Response to Relapse Treatment in Patients with Multiple Sclerosis. Int J MS Care, 14, 148-159.

Ross, A.P., Ben-Zacharia, A., Harris, C., Smrtka, J., 2013. Multiple Sclerosis, Relapses, and the Mechanism of Action of
Adrenocorticotropic Hormone. Frontiers in Neurol., 4 (21), 1-12.

Steinman, L., 2014. Immunology of Relapse and Remission in Multiple Sclerosis. Annu Rev Immunol., 32, 257-281.

Torkildsen, Ø, Myhr, K-M, BØ, L., 2015. DiseaseModifying Treatments for Multiple Sclerosis - A Review of Approved Medications. European Journal of Neurol., 23 (Suppl.1), 18-27.

Totaro, R., Carmine, C.D., Costantino, G., Fantozzi, R., Bellantonio, P., Fuiani, A., Mundi, C., Ruggieri, S., Marini, C., Carolei, A., 2015. Fingolimod Treatment in Relapsing-Remitting Multiple Sclerosis Patients: A Prospective Observational Multicenter Postmarketing Study. Multiple Sclerosis Intern., DOI: 10.1155/2015/763418.

Weinstock-Guttman, B. 2013. An Update on New and Emerging Therapies for RelapsingRemitting Multiple Sclerosis. Am J Manag Care, 19 (17), S343-S354.

Williams, U.E., Oparah, S.K., Philip-Ephraim E.E., 2014. Disease Modifying Therapy in Multiple Sclerosis. Intern. Schol. Research Notic., http://dx.doi.org/10.1155/2014/307064

Wu, G.F., Alvarez, E., 2011. The Immunopathophysiology of Multiple Sclerosis. Neurol Clin., 29 (2), 257-278. 